\title{
C-reactive protein level is a prognostic indicator for survival and improves the predictive ability of the R-IPI score in diffuse large B-cell lymphoma patients
}

K T Troppan ${ }^{1,8}$, K Schlick ${ }^{2,8}$, A Deutsch ${ }^{1}$, T Melchardt' ${ }^{2}$ A Egle ${ }^{2}$, T Stojakovic ${ }^{3}$, C Beham-Schmid ${ }^{4}$, L Weiss $^{2}$, D Neureiter ${ }^{5}$, K Wenzl $^{1}$, R Greil ${ }^{2}$, P Neumeister $^{1}$ and M Pichler ${ }^{\star}, 6,7$

${ }^{1}$ Division of Hematology, Department of Internal Medicine, Medical University of Graz (MUG), Graz, Austria; ${ }^{2}$ Third Medical Department with Hematology and Medical Oncology, Hemostaseology, Rheumatology and Infectious Diseases, Laboratory for Immunological and Molecular Cancer Research, Oncologic Center, Paracelsus Medical University Salzburg, Salzburg, Austria; ${ }^{3}$ Clinical Institute of Medical and Chemical Laboratory Diagnostics, Medical University of Graz (MUG), Graz, Austria; ${ }^{4}$ Institute of Pathology, Medical University of Graz (MUG), Graz, Austria; Institute of Pathology, Paracelsus Medical University Salzburg, Salzburg, Austria; ${ }^{6}$ Department of Experimental Therapeutics, The University of Texas MD Anderson Cancer Center, 1515 Holcombe Boulevard, Houston 77030, TX, USA and 'Division of Oncology, Department of Internal Medicine, Medical University of Graz (MUG), Graz, Austria

Background: High levels of C-reactive protein (CRP), an acute phase protein, proofed being associated with decreased clinical outcome in small-scale studies in diffuse large B-cell lymphoma (DLBCL). The aim of this study was to evaluate the prognostic impact of pretreatment CRP levels on overall survival (OS) and disease-free survival (DFS) in a large bicentre study of DLBCL patients.

Methods: Data from 477 DLBCL patients, diagnosed and treated between 2004 and 2013 at two Austrian centres, were evaluated retrospectively. The prognostic influence of CRP and other factors, including age, tumour stage, and revised International Prognostic Index (R-IPI) on 5-year OS and 5-year DFS, were studied by Kaplan-Meier curves as well as univariate and multivariate Cox regression models. Influence of CRP on the predictive accuracy of the R-IPI score was determined by the Harrell concordance index.

Results: Kaplan-Meier curves revealed elevated CRP as a factor for decreased 5-year OS and DFS in DLBCL patients $(P<0.001$, log-rank test). An independent significant association between high CRP levels and poor clinical outcome in multivariate analysis for 5-year OS ( $H R=1.51, \mathrm{Cl} 95 \%=1.04-2.20, P=0.031)$ and for DFS (HR=1.91, Cl 95\%=1.28-2.85, $P=0.002)$ was found. The estimated concordance index was 0.75 using the original R-IPI score and 0.79 when CRP was added.

Conclusions: In the present study, we demonstrated high CRP levels at diagnosis of DLBCL as an independent poor prognostic factor for clinical outcome. Adding CRP to the well-established prognostic models such as the R-IPI score might improve their predictive ability.

\footnotetext{
*Correspondence: Professor M Pichler; E-mail: mpichler@mdanderson.org

${ }^{8}$ These authors contributed equally to this work.
}

Received 18 February 2014; revised 17 April 2014; accepted 28 April 2014; published online 29 May 2014

(c) 2014 Cancer Research UK. All rights reserved 0007-0920/14 
The most common form of aggressive lymphomas are diffuse large B-cell lymphoma (DLBCL), accounting for $30-40 \%$ of newly diagnosed non-Hodgkin's lymphomas (NHL) (Lenz and Staudt, 2010). For several years, standard immunochemotherapy with rituximab, cyclophosphamide, doxorubicin, vincristine, and prednisone (R-CHOP) is administered, and the disease can be considered potentially curable. Nevertheless, approximately onethird of patients with advanced-stage DLBCL will still be refractory to therapy or will relapse (Flowers et al, 2010).

Currently, clinicians rely on prognostic schemes that imply clinical risk factors to predict the risk for disease progression, relapse, and death of patients with aggressive NHL. One of the most commonly used schemes of rating, the International Prognostic Index (IPI) for lymphomas, involves five features: age, tumour stage, serum lactate dehydrogenase (LDH) concentration, performance status, and the number of extranodal disease sites. The IPI distinguishes four risk groups with different 5-year overall survival (OS), ranging from $26 \%$ to $73 \%$ (Shipp, 1993). In the era of rituximab, a revised IPI (R-IPI) has been introduced, showing superior prediction in outcome of DLBCL patients, treated with standard immunochemotherapy (Sehn et al, 2007).

Recently, the development of molecular signatures, identified through gene expression profiling (GEP), has helped to identify new therapeutic targets to complement standard therapy and proved to be useful in adding prognostic information (Alizadeh et al, 2000). GEP has revealed three subtypes of aggressive lymphoma, discerning in developmental stage and usage of different oncogenic pathways. Patients with germinal centre B cell-like DLBCL have a 5-year survival rate of $60 \%$, as compared with a rate of $<40 \%$ for patients with activated B cell-like DLBCL, whereas a third, smaller group lies in between (Rosenwald et al, 2002). However, rating by molecular markers is associated with high costs, laboratory efforts, and time-consuming procedures and is not routinely available in most laboratories. Therefore, the search for cheap and easily applicable prognostic markers that might help to improve the prognostic accuracy of existing models is needed.

The association between inflammation and cancer has been previously described (Coussens and Werb, 2002). Various inflammatory parameters have been linked with cancer development and progression (Ramsey et al, 2006; Groblewska et al, 2012; Poole et al, 2013; Purdue et al, 2013; Pichler et al, 2013a, b). One of the most commonly used inflammatory markers in routine diagnostic is the C-reactive protein (CRP), an acute phase protein, produced by the liver after interleukin- 6 and other cytokine stimuli. Its prognostic role in various solid and hematological cancer types has been demonstrated recently (Allin and Nordestgaard, 2011; Hong et al, 2012; Hall et al, 2013; Toiyama et al, 2013). In DLBCL, only a few small-scale studies that include some of them before the rituximab era have been reported (Elahi et al, 1998; Legouffe et al, 1998; Herishanu et al, 2007; Cao et al, 2012). Therefore, in the present study we aimed to validate the prognostic significance of the pretreatment CRP level in a large middle European bicentre study including two cohorts of patients with DLBCL and test its value to improve the predictive ability of the well-established R-IPI prognosis score.

\section{PATIENTS AND METHODS}

This retrospective bicentre study includes data from 477 patients who were diagnosed with DLBCL according to the 2008 World Health Organisation (Campo et al, 2011) criteria between January 2004 and April 2013. Of the 477 patients, 288 patients (cohort 1) were diagnosed and treated at the Division of Hematology at the Medical University of Graz and 189 patients (cohort 2) were diagnosed and treated at the third Medical Department at the Paracelsus Medical University Salzburg in Austria. All of the clinico-pathological data are retrieved from medical records from either of the institutions, as well as from pathology reports of the Institute of Pathology at the same institution. Clinico-pathological parameters include histologically confirmed DLBCL, gender, age, and Ann Arbor stage. The laboratory data, including whole blood counts, derived neutrophil-lymphocyte ratio (dNLR), and CRP, were obtained by prediagnosis exploration 1-7 days before histological-proven diagnosis. A preoperative plasma CRP level is routinely measured at our institutions for nearly all patients who underwent a consecutive chemotherapeutic regimen. Of note, for

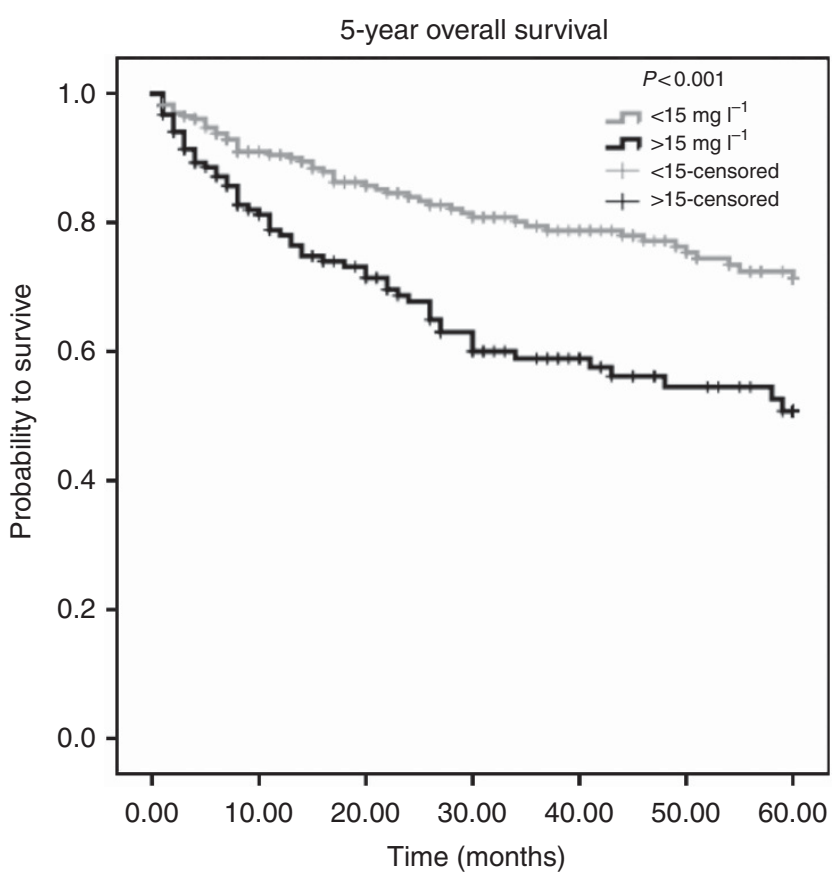

Figure 1. Kaplan-Meier curves for 5 -year OS regarding low $\left(<15 \mathrm{mgl}^{-1}\right)$ vs high $\left(>15 \mathrm{mgl}^{-1}\right)$ CRP levels $(P<0.001)$.

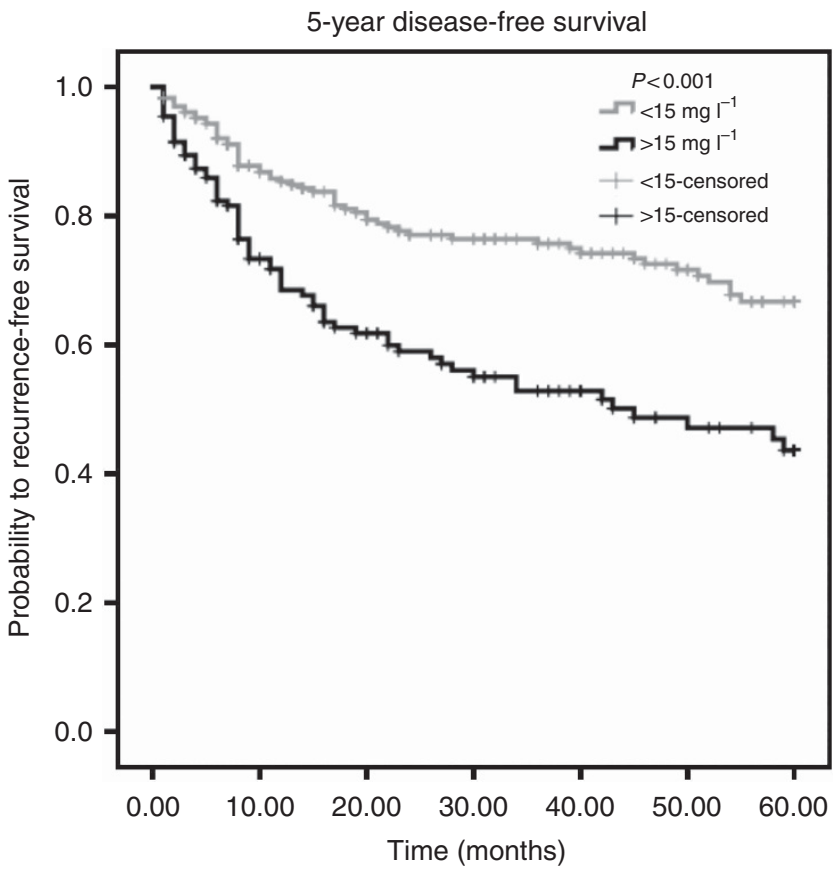

Figure 2. Kaplan-Meier curves for 5-year DFS regarding low $\left(<15 \mathrm{mgl}^{-1}\right)$ vs high $\left(>15 \mathrm{mgl}^{-1}\right)$ CRP levels $(P<0.001)$. 
23 of the 311 patients in cohort $1(7 \%)$ and 24 of the 213 patients in cohort $2(11 \%)$, CRP or other values were not available, and therefore these patients had been not included into the final analysis. Patients were treated by standard R-CHOP regimen, CHOP-like, or third-generation anthracycline-containing regimens but all received a combination, including the monoclonal antibody rituximab. Posttreatment surveillance included routine clinical and laboratory examination. The predominant imaging method used was computer tomography. Follow-up evaluations were performed every 3 months during the first 5 years and annually thereafter. Patients were excluded in case of seropositivity of HIV or missing laboratory parameters at diagnosis. Dates of death were obtained from clinical records, the central registry of the Austrian Bureau of Statistics, or by telephone calls to their relatives. Five-year OS is defined as the time (in months) from the date of diagnosis until death due to any cause within the follow-up period. Five-year disease-free survival (DFS) is defined as the time (in months) from the date of diagnosis until the recurrence of the disease being confirmed radiologically or histologically. The study was approved by the local ethical committee of the Medical University of Graz (No. 25-434 ex 12/13) and by the Ethics Committee of the provincial government of Salzburg, Austria (415-EP/73/127-2012).

Statistical analyses. The primary end point of the study was 5 -year OS; the secondary end point was 5-year DFS. In a first step, an optimal cutoff value for CRP to differentiate between survival and death in cohort 1 from Graz was determined by applying receiver operating curve (ROC) analysis as previously reported (Absenger et al, 2013). Using this cutoff value of $15 \mathrm{mgl}^{-1}$ for the whole cohort, the association between CRP levels and clinico-pathological parameters was evaluated by non-parametric tests (chi-square test, Mann-Whitney U-test). Kaplan-Meier curves were used to show an association between CRP levels with OS and DFS, and log-rank test was used for comparison. Backward stepwise multivariate Cox proportional analysis was performed to determine the influence of clinico-pathological variables, meaning whether they are significantly associated with clinical outcome in univariate analysis of 5-year OS and 5-year DFS. Hazard ratios (HRs) estimated from the Cox analysis are reported as relative risks with corresponding 95\% confidence intervals (CIs). Patients were categorised according to the R-IPI prognosis risk groups. Harrell's concordance index (c-index) was calculated using the individual R-IPI groups followed by the addition of the CRP levels (Harrell et al, 1982). All statistical analyses were performed using the Statistical Package for Social Sciences version 17.0 (SPSS Inc., Chicago, IL, USA) or the STATA statistical software (College Station, TX, USA). A two-sided $P<0.05$ was considered statistically significant.

\section{RESULTS}

Overall, 190 (39.8\%) male and 287 (60.2\%) female patients with DLBCL were included in the study cohort. The median age at diagnosis was 68 (interquartile range 59-77) years. The Ann Arbor tumour stage was defined as stage I in 127 (26.6\%) patients; stage II in $121(25.4 \%)$ patients, stage III in $102(21.4 \%)$ patients, and stage IV in 127 (26.6\%) patients. Regarding the R-IPI, 44 (9.2\%) had a very good R-IPI, 249 (52.2\%) had a good R-IPI, and $184(38.6 \%)$

Table 1. Univariate and multivariate analysis of clinico-pathological parameters for the prediction of 5-year OS in patients with diffuse large B-cell lymphoma $(n=477)$

Univariate analysis

Multivariate analysis

\begin{tabular}{|c|c|c|c|c|}
\hline \multirow[b]{2}{*}{ Parameter } & \multicolumn{2}{|c|}{ Univariate analysis } & \multicolumn{2}{|c|}{ Multivariate analysis } \\
\hline & HR $(95 \% \mathrm{Cl})$ & $P$-value & HR $(95 \% \mathrm{Cl})$ & $P$-value \\
\hline \multicolumn{5}{|l|}{ Gender } \\
\hline $\begin{array}{l}\text { Female }(n=287) \\
\text { Male }(n=190)\end{array}$ & $\begin{array}{c}1 \text { (referent) } \\
0.691(0.50-0.957)\end{array}$ & 0.026 & $\begin{array}{c}1 \text { (referent) } \\
0.81(0.58-1.13)\end{array}$ & 0.212 \\
\hline \multicolumn{5}{|l|}{ Age at diagnosis (years) } \\
\hline $\begin{array}{l}<60(n=180) \\
\geqslant 60(n=297)\end{array}$ & $\begin{array}{c}1 \text { (referent) } \\
2.86(1.90-4.3)\end{array}$ & $<0.001$ & $\begin{array}{c}1 \text { (referent) } \\
1.77(1.12-2.81)\end{array}$ & 0.015 \\
\hline \multicolumn{5}{|l|}{ Clinical stage (Ann Arbor) } \\
\hline $\begin{array}{l}\text { I and II }(n=248) \\
\text { III and IV }(n=229)\end{array}$ & $\begin{array}{c}1 \text { (referent) } \\
1.86(1.34-2.6)\end{array}$ & $<0.001$ & $\begin{array}{c}1 \text { (referent) } \\
1.06(0.68-1.65)\end{array}$ & 0.802 \\
\hline \multicolumn{5}{|l|}{ R-IPI } \\
\hline $\begin{array}{l}\text { Very good }+ \text { good }(n=293) \\
\text { Poor }(n=184)\end{array}$ & $\begin{array}{c}1 \text { (referent) } \\
2.86(2.06-3.98)\end{array}$ & $<0.001$ & $\begin{array}{c}1 \text { (referent) } \\
2.02(1.28-3.21)\end{array}$ & 0.003 \\
\hline \multicolumn{5}{|l|}{ CRP } \\
\hline $\begin{array}{l}<15 \mathrm{mgl}^{-1}(n=266) \\
\geqslant 15 \mathrm{mgl}^{-1}(n=211)\end{array}$ & $\begin{array}{c}1 \text { (referent) } \\
2.43(1.74-3.39)\end{array}$ & $<0.001$ & $\begin{array}{c}1 \text { (referent) } \\
1.51(1.04-2.20)\end{array}$ & 0.031 \\
\hline \multicolumn{5}{|l|}{$d N L R^{a}$} \\
\hline $\begin{array}{l}<4(n=367) \\
\geqslant 4(n=85)\end{array}$ & $\begin{array}{c}1 \text { (referent) } \\
1.58(1.08-2.31)\end{array}$ & 0.018 & $\begin{array}{c}1 \text { (referent) } \\
1.28(0.87-1.89)\end{array}$ & 0.205 \\
\hline
\end{tabular}


patients were classified as a poor R-IPI. Overall, $156(32.7 \%)$ patients died, and $184(38.6 \%)$ had disease recurrence by their most recent follow-up visit. Two hundred and seventy (56.6\%) patients received a therapy with $\mathrm{R}-\mathrm{CHOP}, 175$ (36.7\%) received CHOP-like, and 32 (5.2\%) received another therapy. The median number of administered therapy was six cycles.

Using ROC analysis, a cutoff value of $15 \mathrm{mgl}^{-1}$ for CRP was determined as optimal to discriminate between patients' survival and death in the larger cohort 1. Applied on the whole cohort of 477 patients, a highly significant association $(P<0.001$, log-rank test $)$ between high CRP levels and poor OS could be determined (Figure 1). A negative prognostic impact of high CRP levels for 5 -year DFS could also be identified $(P<0.001, \log$-rank test, Figure 2$)$.

Moreover, the association between CRP levels and other clinicopathological factors was tested, and a correlation to advanced tumour stage $(P<0.001)$ and a poor R-IPI $(P<0.001)$ was observed. No association of CRP with age or gender was found (data not shown). There was neither a correlation of the CRP levels and the number of administered therapy cycles (spearman $\mathrm{R}=0.33$, $P=0.576)$ nor a significant association between CRP levels and completed therapy cycles (defined as $\leqslant 6$ cycles, $P=0.754$ ).

Univariate Cox proportional analysis identified gender $(P=0.026)$, older age $(<60$ vs $\geqslant 60, P<0.001)$, high tumour stage (stage I + II $v s$ stage III + IV,$P<0.001$ ), elevated CRP $\left(<15 \mathrm{mgl}^{-1}\right.$ vs $\left.>15 \mathrm{mgl}^{-1}, P<0.001\right)$, $\operatorname{dNLR}(<4$ vs $>4$, $P=0.018$ ), and high R-IPI (very good and good $v s$ poor, $P<0.001$ ) as prognosticators of poor outcome for patients' 5-year OS (Table 1). To determine the independent prognostic value of $\mathrm{CRP}$, a multivariate analysis, including gender, age, tumour stage,
R-IPI, and CRP levels, was performed. We identified age $(P=0.015)$, R-IPI $(P=0.003)$, and high CRP $(P=0.031)$ as independent prognostic factors for 5-year OS (Table 1).

Regarding the 5-year DFS, univariate analysis showed statistical significance for older age $(<60 v s \geqslant 60, P<0.001)$, high tumour stage (stage I + II $v s$ stage III + IV,$P<0.001)$, elevated CRP $\left(<15 \mathrm{mgl}^{-1}\right.$ vs $>15 \mathrm{mgl}^{-1}, P<0.001$ ), and high R-IPI (very good + good $v s$ poor, $P<0.001$ ) as prognosticators of poor outcome (Table 2$)$. In the multivariate analysis, we identified a high age $(P=0.002)$, high tumour stage $(P=0.031)$, and high CRP $(P=0.002)$ as independent prognostic factors for 5-year DFS (Table 2).

Finally, regarding 5-year OS, the c-index of the R-IPI prognostic model was 0.75 compared with 0.79 when CRP level was supplemented.

\section{DISCUSSION}

CRP has been identified as a prognostic variable in various solid as well as hematological malignancies yet. Increased CRP concentrations have been found to be associated with poor OS in many types of cancer, including colorectal carcinoma, prostate cancer, soft tissue sarcoma, pancreatic cancer, and small cell lung cancer (Hong et al, 2012; Hall et al, 2013; Toiyama et al, 2013; Szkandera et al, 2013a,b).

The role of CRP in the prognosis of non-Hodgkin lymphoma patients had also been well studied in the pre-Rituximab era (Pavlidis et al, 1993; Legouffe et al, 1998). More recently, the

Table 2. Univariate and multivariate analysis of clinico-pathological parameters for the prediction of 5-year DFS in patients with diffuse large B-cell lymphoma $(n=477)$

\begin{tabular}{|c|c|c|c|c|}
\hline \multirow[b]{2}{*}{ Parameter } & \multicolumn{2}{|c|}{ Univariate analysis } & \multicolumn{2}{|c|}{ Multivariate analysis } \\
\hline & $\mathrm{HR}(95 \% \mathrm{Cl})$ & $P$-value & $\mathrm{HR}(95 \% \mathrm{Cl})$ & $P$-value \\
\hline \multicolumn{5}{|l|}{ Gender } \\
\hline $\begin{array}{l}\text { Female }(n=287) \\
\text { Male }(n=190)\end{array}$ & $\begin{array}{c}1 \text { (referent) } \\
0.94(0.64-1.39)\end{array}$ & 0.754 & $\begin{array}{c}1 \text { (referent) } \\
0.80(0.54-1.19)\end{array}$ & 0.269 \\
\hline \multicolumn{5}{|l|}{ Age at diagnosis (years) } \\
\hline $\begin{array}{l}<60(n=180) \\
\geqslant 60(n=297)\end{array}$ & $\begin{array}{c}1 \text { (referent) } \\
2.79(1.63-4.76)\end{array}$ & $<0.001$ & $\begin{array}{c}1 \text { (referent) } \\
2.51(1.42-4.44)\end{array}$ & 0.002 \\
\hline \multicolumn{5}{|l|}{ Clinical stage (Ann Arbor) } \\
\hline $\begin{array}{l}I \text { and II }(n=248) \\
\text { III and IV }(n=229)\end{array}$ & $\begin{array}{c}1 \text { (referent) } \\
2.29(1.53-3.41)\end{array}$ & $<0.001$ & $\begin{array}{c}1 \text { (referent) } \\
1.79(1.05-3.03)\end{array}$ & 0.031 \\
\hline \multicolumn{5}{|l|}{ R-IPI } \\
\hline $\begin{array}{l}\text { Very good }+ \text { good }(n=293) \\
\text { Poor }(n=184)\end{array}$ & $\begin{array}{c}1 \text { (referent) } \\
2.80(1.89-4.16)\end{array}$ & $<0.001$ & $\begin{array}{c}1 \text { (referent) } \\
1.50(0.88-2.56)\end{array}$ & 0.137 \\
\hline \multicolumn{5}{|l|}{ CRP } \\
\hline $\begin{array}{l}<15 \mathrm{mgl}^{-1}(n=266) \\
\geqslant 15 \mathrm{mgl}^{-1}(n=211)\end{array}$ & $\begin{array}{c}1 \text { (referent) } \\
2.33(1.58-3.45)\end{array}$ & $<0.001$ & $\begin{array}{c}1 \text { (referent) } \\
1.91(1.28-2.85)\end{array}$ & 0.002 \\
\hline \multicolumn{5}{|l|}{$d N L R^{a}$} \\
\hline $\begin{array}{l}<1.8(n=141) \\
\geqslant 1.8(n=311)\end{array}$ & $\begin{array}{c}1 \text { (referent) } \\
1.32(0.85-2.05)\end{array}$ & 0.214 & $\begin{array}{c}1 \text { (referent) } \\
1.20(0.76-1.87)\end{array}$ & 0.434 \\
\hline
\end{tabular}


correlation between CRP, IPI, and long-term survival in DLBCL was investigated but only in a small group of 94 Chinese patients (Cao et al, 2012).

Hence prognostic significance for increased CRP in DLBCL has been indicated; however, a validation in a large middle European cohort with different genetic background is still missing. In the present study, a significant association between elevated CRP and poor outcome of 477 DLBCL patients at two Austrian centres could be confirmed. Univariate analysis, as well as multivariate analysis, identified the pretreatment CRP level as a useful prognostic marker of 5-year OS and 5-year-DFS. Furthermore, by integrating the CRP levels in the well-established R-IPI score improved the predictive ability of this score by $4 \%$. Beyond the results of our study that focuses on the CRP levels before treatment initiation, Herishanu et al (2007) identified the early-mid treatment CRP level as a reliable marker in NHL patients to predict DFS and OS. Patients who did not achieve low early-mid treatment CRP levels had earlier disease progression or earlier relapses and also appear to have an inferior OS. However, $<100$ patients were included in this study, and further confirmation in larger series is needed.

Our findings are in line with previously reported data also demonstrating a prognostic value for CRP levels in various other hematological disorders. For instance, in extranodal natural killer/ T-cell lymphoma, a heterogeneous histopathological subtype of NHL with increased incidence in Asia, high CRP levels were found to impair the natural course of disease ( $\mathrm{Li}$ et al, 2013a). In this study, beside lower rates of complete remissions, inferior DFS and inferior OS were found in patients with high pretreatment CRP levels. Therefore the authors constructed a new prognostic model, including CRP, age, hypoalbuminemia, and elevated LDH levels, to identify different prognostic subgroups (Li et al, 2013a).

The reason for the general poor prognosis associated with higher CRP levels remains elusive. Recently, Yang et al (2007) demonstrated that CRP enhances cell proliferation under stressed conditions and protected myeloma cells from chemotherapy druginduced apoptosis by binding to activating $\mathrm{Fc} \gamma$ receptors, activating PI3K/Akt, ERK, and NF-kappaB pathways and inhibiting caspase cascade activation induced by chemotherapy drugs. Whether these or other mechanisms may have a role in DLBCL has to be clarified.

Apart from CRP, other inflammatory markers have been found to be involved in the development and progression of lymphoma. Purdue et al (2013) conducted a prospective study of 67 serum immune and inflammatory markers to identify possible predictors of NHL. A significant association between the elevated levels of BCA-1, sTNFR2 and sVEGFR2 and increased risk of lymphoma development, several years after blood collection, could be shown.

Nevertheless, comparing the costs and availability of these markers, CRP seems to be more convenient for routine use. Interestingly, using the previously published dNLR (Troppan et al, 2014) we could not detect an independent value of this blood ratio when exploring this parameter in the multivariate analysis for both cohorts. This means that the previously published cutoff values may be not optimal to generally apply for all cohorts. In addition, it seems that CRP outperforms dNLR as a prognosticator, which should also be considered in future prospective trials. Several other blood-based inflammatory parameters have been suggested to have an important role in NHL cancer progression and prognosis (Purdue et al, 2013; Li et al, 2013b; Troppan et al, 2014; Porrata et al, 2010, 2014). These include the Glasgow prognostic score, the fibrinogen levels, the neutrophil-lymphocyte ratio, and the lymphocyte-monocyte ratio. All these studies have been performed on retrospective data sets, including in part several hundreds of patients. Future prospective trials should assemble a panel of these markers and evaluate the prognostic value of these parameters for differentiating patients with varying clinical outcome. Each of these parameters can add additional prognostic value and supplement established risk scores such as the R-IPI or the recently proposed NCCN-IPI to improve prediction of individual patients' outcome (Sehn et al, 2007; Zhou et al, 2014).

Together with the whole blood count and differential leukocyte count, CRP is routinely measured in most medical laboratories, which make an implementation for clinical routine more easily. Our study is not without limitations. As with all retrospective studies, a selection bias cannot be excluded. Taken together, the role for pretreatment CRP levels in risk stratification should be strongly considered. In our opinion, the integration in preexisting prognostic risk models for a refined new risk stratification score should be prospectively evaluated. In the end, an improvement of the existing risk stratification tools could result in better treatment choices for DLBCL patients.

\section{CONFLICT OF INTEREST}

The authors declare no conflict of interest.

\section{REFERENCES}

Absenger G, Szkandera J, Pichler M, Stotz M, Arminger F, Weissmueller M, Schaberl-Moser R, Samonigg H, Stojakovic T, Gerger A (2013) A derived neutrophil to lymphocyte ratio predicts clinical outcome in stage II and III colon cancer patients. Br J Cancer 109(2): 395-400.

Alizadeh AA, Eisen MB, Davis RE, Ma C, Lossos IS, Rosenwald A, Boldrick JC, Sabet H, Tran T, Yu X, Powell JI, Yang L, Marti GE, Moore T, Hudson Jr J, Lu L, Lewis DB, Tibshirani R, Sherlock G, Chan WC, Greiner TC, Weisenburger DD, Armitage JO, Warnke R, Levy R, Wilson W, Grever MR, Byrd JC, Botstein D, Brown PO, Staudt LM (2000) Distinct types of diffuse large B-cell lymphoma identified by gene expression profiling. Nature 403(6769): 503-511.

Allin KH, Nordestgaard BG (2011) Elevated C-reactive protein in the diagnosis, prognosis, and cause of cancer. Crit Rev Clin Lab Sci 48(4): 155-170.

Campo E, Swerdlow SH, Harris NL, Pileri S, Stein H, Jaffe ES (2011) WHO classification of tumours of hematopoietic and lymphoid tissues. Blood 117(19): 5019-5032.

Cao Y, Shi YX, Chen JO, Tan YT, Cai YC, Luo HY, Qiu MZ, Cai XY, Jin Y, Sun YL, Jiang WQ (2012) Serum C- reactive protein as an important prognostic variable in patients with diffuse large B cell lymphoma. Tumour Biol 33(4): 1039-1044.

Coussens LM, Werb Z (2002) Inflammation and cancer. Nature 420(6917): 860-867.

Elahi MM, McMillan DC, McArdle CS, Angerson WJ, Soukop M, Johnstone J, Sattar N (1998) The systemic inflammatory response predicts overall and cancer specific survival in patients with malignant lymphoma. Leuk Lymphoma 31(3-4): 351-357.

Flowers CR, Sinha R, Vose JM (2010) Improving outcomes for patients with diffuse large B-cell lymphoma. CA Cancer J Clin 60(6): 393-408.

Groblewska M, Mroczko B, Sosnowska D, Szmitkowski M (2012) Interleukin 6 and C-reactive protein in esophageal cancer. Clin Chim Acta 413(19-20): 1583-1590.

Hall WA, Nickleach DC, Master VA, Prabhu RS, Rossi PJ, Godette K, Cooper S, Jani AB (2013) The association between C-reactive protein (CRP) level and biochemical failure-free survival in patients after radiation therapy for nonmetastatic adenocarcinoma of the prostate. Cancer 119(18): 3272-3279.

Harrell Jr FE, Califf RM, Pryor DB, Lee KL, Rosati RA (1982) Evaluating the yield of medical tests. JAMA 247(18): 2543-2546.

Herishanu Y, Perry C, Braunstein R, Metser U, Goor O, Rogowski O, Berliner S, Polliack A, Naparstek E (2007) Early-mid treatment C-reactive protein level is a prognostic factor in aggressive non-Hodgkin's lymphoma. Eur J Haematol 79(2): 150-154.

Hong S, Kang YA, Cho BC, Kim DJ (2012) Elevated serum C-reactive protein as a prognostic marker in small cell lung cancer. Yonsei Med J 53: 111-117.

Legouffe E, Rodriguez C, Picot MC, Richard B, Klein B, Rossi JF, Commes T (1998) C-reactive protein serum level is a valuable and simple prognostic marker in non Hodgkin's lymphoma. Leuk Lymphoma 31(3-4): 351-357. 
Lenz G, Staudt LM (2010) Aggressive lymphomas. N Engl J Med 362: $1417-1429$.

Li YJ, Jiang WQ, Huang JJ, Xia ZJ, Huang HQ, Li ZM (2013b) The Glasgow Prognostic Score (GPS) as a novel and significant predictor of extranodal natural killer/T-cell lymphoma, nasal type. Am J Hematol 88(5): 394-399.

Li YJ, Li ZM, Xia Y, Huang JJ, Huang HQ, Xia ZJ, Lin TY, Li S, Cai XY, Wu-Xiao ZJ, Jiang WQ (2013a) Serum C-reactive protein (CRP) as a simple and independent prognostic factor in extranodal natural killer/T-cell lymphoma, nasal type. PLoS One 8(5): e64158.

Pavlidis AN, Kalef-Ezra J, Bourantas LC, Lambrou A, Mavridis A (1993) Serum tumor markers in non-Hodgkin's lymphomas and chronic lymphocytic leukemia. Int J Biol Markers 8(1): 14-20.

Pichler M, Hutterer GC, Stoeckigt C, Chromecki TF, Stojakovic T, Golbeck S, Eberhard K, Gerger A, Mannweiler S, Pummer K, Zigeuner R (2013b) Validation of the pre-treatment neutrophil-lymphocyte ratio as a prognostic factor in a large European cohort of renal cell carcinoma patients. Br J Cancer 108(4): 901-907.

Pichler M, Hutterer GC, Stojakovic T, Mannweiler S, Pummer K, Zigeuner R (2013a) High plasma fibrinogen level represents an independent negative prognostic factor regarding cancer-specific, metastasis-free, as well as overall survival in a European cohort of non-metastatic renal cell carcinoma patients. Br J Cancer 109(5): 1123-1129.

Poole EM, Lee IM, Ridker PM, Buring JE, Hankinson SE, Tworoger SS (2013) A prospective study of circulating C-reactive protein, interleukin-6, and tumor necrosis factor $\alpha$ receptor 2 levels and risk of ovarian cancer. Am J Epidemiol 178(8): 1256-1264.

Porrata LF, Ristow K, Habermann T, Inwards DJ, Micallef IN, Markovic SN (2010) Predicting survival for diffuse large B-cell lymphoma patients using baseline neutrophil/lymphocyte ratio. Am J Hematol 85(11) 896-899.

Porrata LF, Ristow KM, Habermann TM, Witzig TE, Colgan JP, Inwards DJ, Ansell SM, Micallef IN, Johnston PB, Nowakowski G, Thompson CA, Markovic SN (2014) Peripheral blood absolute lymphocyte/monocyte ratio during rituximab, cyclophosphamide, doxorubicin, vincristine and prednisone treatment cycles predicts clinical outcomes in diffuse large B-cell lymphoma. Leuk Lymphoma; e-pub ahead of print 19 March 2014.

Purdue MP, Hofmann JN, Kemp TJ, Chaturvedi AK, Lan Q, Park JH, Pfeiffer RM, Hildesheim A, Pinto LA, Rothman N (2013) A prospective study of 67 serum immune and inflammation markers and risk of non-Hodgkin lymphoma. Blood 122(6): 951-957.

Ramsey S, Lamb GW, Aitchison M, McMillan DC (2006) The longitudinal relationship between circulating concentrations of C-reactive protein, interleukin-6 and interleukin-10 in patients undergoing resection for renal cancer. Br J Cancer 95(8): 1076-1080.

Rosenwald A, Wright G, Chan WC, Connors JM, Campo E, Fisher RI, Gascoyne RD, Muller-Hermelink HK, Smeland EB, Giltnane JM, Hurt EM, Zhao H, Averett L, Yang L, Wilson WH, Jaffe ES, Simon R, Klausner RD, Powell J, Duffey PL, Longo DL, Greiner TC, Weisenburger DD,
Sanger WG, Dave BJ, Lynch JC, Vose J, Armitage JO, Montserrat E, López-Guillermo A, Grogan TM, Miller TP, LeBlanc M, Ott G, Kvaloy S, Delabie J, Holte H, Krajci P, Stokke T, Staudt LM (2002) The use of molecular profiling to predict survival after chemotherapy for diffuse large B-cell lymphoma. N Engl J Med 346(25): 1937-1947.

Sehn LH, Berry B, Chhanabhai M, Fitzgerald C, Gill K, Hoskins P, Klasa R, Savage KJ, Shenkier T, Sutherland J, Gascoyne RD, Connors JM (2007) The revised International Prognostic Index (R-IPI) is a better predictor of outcome than the standard IPI for patients with diffuse large B-cell lymphoma treated with R-CHOP. Blood 109(5): 1857-1861.

Shipp MA on behalf of The International Non-Hodgkin's Lymphoma Prognostic Factors Project (1993) A predictive model for aggressive non-Hodgkin's lymphoma. $N$ Engl J Med 329(14): 987-994.

Szkandera J, Gerger A, Liegl-Atzwanger B, Absenger G, Stotz M, Samonigg H, Maurer-Ertl W, Stojakovic T, Ploner F, Leithner A, Pichler M (2013b) Validation of the prognostic relevance of plasma C-reactive protein levels in soft-tissue sarcoma patients. Br J Cancer 109(9): 2316-2322.

Szkandera J, Stotz M, Absenger G, Stojakovic T, Samonigg H, Kornprat P, Schaberl-Moser R, Alzoughbi W, Lackner C, Ress AL, Seggewies FS, Gerger A, Hoefler G, Pichler M (2013a) Validation of C-reactive protein levels as a prognostic indicator for survival in a large cohort of pancreatic cancer patients. Br J Cancer 110(1): 183-188.

Toiyama Y, Fujikawa H, Koike Y, Saigusa S, Inoue Y, Tanaka K, Mohri Y, Miki C, Kusunoki M (2013) Evaluation of preoperative C-reactive protein aids in predicting poor survival in patients with curative colorectal cancer with poor lymph node assessment. Oncol Lett 5(6): 1881-1888.

Troppan K, Deutsch A, Gerger A, Stojakovic T, Beham-Schmid C, Wenzl K, Neumeister P, Pichler M (2014) The derived neutrophil to lymphocyte ratio is an independent prognostic factor in patients with diffuse large B-cell lymphoma. Br J Cancer 110(2): 369-374.

Yang J, Wezeman M, Zhang X, Lin P, Wang M, Qian J, Wan B, Kwak LW, Yu L, Yi Q (2007) Human C-reactive protein binds activating Fcgamma receptors and protects myeloma tumor cells from apoptosis. Cancer Cell 12(3): 252-265.

Zhou Z, Sehn LH, Rademaker AW, Gordon LI, Lacasce AS, CrosbyThompson A, Vanderplas A, Zelenetz AD, Abel GA, Rodriguez MA, Nademanee A, Kaminski MS, Czuczman MS, Millenson M, Niland J, Gascoyne RD, Connors JM, Friedberg JW, Winter JN (2014) An enhanced International Prognostic Index (NCCN-IPI) for patients with diffuse large B-cell lymphoma treated in the rituximab era. Blood 123(6): 837-842.

This work is published under the standard license to publish agreement. After 12 months the work will become freely available and the license terms will switch to a Creative Commons AttributionNonCommercial-Share Alike 3.0 Unported License. 